\title{
Onion (Allium cepa L.)-Derived Nanoparticles Inhibited LPS-Induced Nitrate Production, However, Their Intracellular Incorporation by Endocytosis Was Not Involved in This Effect on RAW264 Cells
}

\author{
Masao Yamasaki ${ }^{1, *(D)}$, Yumi Yamasaki ${ }^{2}$, Rina Furusho ${ }^{1}$, Hayaka Kimura ${ }^{2}$, Ichiro Kamei ${ }^{3}$, Hiroko Sonoda ${ }^{4}$, \\ Masahiro Ikeda ${ }^{4}\left(\mathbb{D}\right.$, Tatsuya Oshima ${ }^{5}$, Kenjiro Ogawa ${ }^{6}$ and Kazuo Nishiyama ${ }^{1}$
}

check for updates

Citation: Yamasaki, M.; Yamasaki, Y.; Furusho, R.; Kimura, H.; Kamei, I.; Sonoda, H.; Ikeda, M.; Oshima, T.; Ogawa, K.; Nishiyama, K. Onion (Allium cepa L.)-Derived Nanoparticles Inhibited LPS-Induced Nitrate Production, However, Their Intracellular Incorporation by Endocytosis Was Not Involved in This Effect on RAW264 Cells. Molecules 2021, 26, 2763. https:// doi.org/10.3390/molecules26092763

Academic Editor: Mirella Nardini

Received: 7 April 2021

Accepted: 3 May 2021

Published: 7 May 2021

Publisher's Note: MDPI stays neutral with regard to jurisdictional claims in published maps and institutional affiliations.

Copyright: (c) 2021 by the authors. Licensee MDPI, Basel, Switzerland. This article is an open access article distributed under the terms and conditions of the Creative Commons Attribution (CC BY) license (https:/ / creativecommons.org/licenses/by/ $4.0 /)$.
1 Department of Biochemistry and Applied Biosciences, University of Miyazaki, 1-1 Gakuenkibanadai-nishi, Miyazaki 889-2192, Japan; shopin_piano@yahoo.co.jp (R.F.); nishiyam@cc.miyazaki-u.ac.jp (K.N.)

2 Faculty of Regional Innovation, University of Miyazaki, 1-1 Gakuenkibanadai-nishi, Miyazaki 889-2192, Japan; yamasakiy@cc.miyazaki-u.ac.jp (Y.Y.); habo26092@gmail.com (H.K.)

3 Department of Forest and Environmental Sciences, University of Miyazaki, 1-1 Gakuenkibanadai-nishi, Miyazaki 889-2192, Japan; kamei@cc.miyazaki-u.ac.jp

4 Department of Veterinary Science, University of Miyazaki, 1-1 Gakuenkibanadai-nishi, Miyazaki 889-2192, Japan; sonoda-h@cc.miyazaki-u.ac.jp (H.S.); a0d302u@cc.miyazaki-u.ac.jp (M.I.)

5 Department of Applied Chemistry, University of Miyazaki, 1-1 Gakuenkibanadai-nishi, Miyazaki 889-2192, Japan; oshimat@cc.miyazaki-u.ac.jp

6 Organization for Promotion of Tenure Track, University of Miyazaki, 1-1 Gakuenkibanadai-nishi, Miyazaki 889-2192, Japan; ogawa.kenjirou.u2@cc.miyazaki-u.ac.jp

* Correspondence: myamasaki@cc.miyazaki-u.ac.jp; Tel.: +81-985-58-7209

\begin{abstract}
The aim of this study was to evaluate the involvement of nanoparticles prepared from Allium cepa L. as anti-inflammatory agents. In the present study, we identified nanoparticles from Allium cepa L. using the ultracentrifugation exosome purification method. The nanoparticles were referred to as $17,000 \times g$ and $200,000 \times g$ precipitates, and they contained quercetins, proteins, lipids, and small-sized RNA. The nanoparticles inhibited nitric oxide production from lipopolysaccharide (LPS)-stimulated RAW264 cells without cytotoxic properties. Cellular incorporation was confirmed by laser microscopic observation after PKH26 staining. The inhibition of caveolae-dependent endocytosis and macropinocytosis significantly prevented the incorporation of the nanoparticles but had no effect on the inhibition of nitric oxide in RAW264 cells. Collectively, the identified nanoparticles were capable of inhibiting the LPS response via extracellular mechanisms. Taken together, the way of consuming Allium cepa L. without collapsing the nanoparticles is expected to provide an efficient anti-inflammatory effect.
\end{abstract}

Keywords: Allium cepa L.; nanovesicles; lipopolysaccharide; endocytosis

\section{Introduction}

The health-promoting effects of natural plant resources, especially vegetables and fruits, have attracted attention not only from researchers but also among general consumers. Numerous studies have focused on the identification and purification of active components in food, and these studies have certainly contributed to the development of functional foods. Although these studies enabled depicting the detailed mechanisms of food function at the molecular level, we are interested in the difference between unpurified or unprocessed foods and purified compounds in terms of their health-promoting effects. Actually, accumulated evidence indicates why eating raw and unprocessed foods should be prioritized from the point of view of the prevention of various diseases [1,2]. One intriguing explanation of this is eating organellas such as mitochondria, chloroplast and vacuoles in the case of raw and unprocessed food [3-5]. Therefore, the ingestion of plant cell 
structures may at least partly explain the health benefit of consuming raw and unprocessed foods. In this context, exosome-like nanoparticles found in various vegetables and fruit have health-promoting effects. These nanoparticles are carriers for microRNAs, proteins, lipids, and vitamins [6-11]. The encapsulation of these compounds might confer protection against degradation and further metabolism, and the delivery of these nanoparticles to the target tissues or cells might manipulate cellular function [5]. For instance, ginger-derived nanoparticles, but not those found in grapes, grapefruits or carrots, strongly induce antiinflammatory cytokines, suggesting differences in the physiological properties of these species [6]. Interestingly, extracellular vesicles can be found even in dried and heated plants $[10,11]$, presenting an attractive and novel approach for the evaluation of food function not only in fresh plants but also appropriate food processing. Onion (Allium cepa L.) is one of the most popular vegetables in the world and is well known for its health benefits. It is rich in flavonoids, such as quercetin and its glucosides, sulfuric compounds that are responsible for the physiological function of onion [12,13]. Among its physiological functions, anti-inflammation is one of the most interesting; the anti-inflammatory property suggests that these components can prevent and alleviate inflammatory-related disorders, such as allergies and lifestyle diseases [14,15]. A previous in vitro study also revealed that onion peel extract inhibits the lipopolysaccharide (LPS)-induced response in human colon cancer cells [16], and crude onion powder inhibits the receptor activator of nuclear factor kappa-B ligand (RANKL)-induced nuclear factor kappa-B (NF-kB) activation in RAW264.7 cells [17]. Based on previous studies, it can be postulated that nanoparticles are ubiquitously found in vegetables and fruits. In this study, we hypothesized that nanoparticles can be prepared from onions, and these particles have anti-inflammatory properties.

The nanoparticles are likely to collapse and disappear during excess food processing. The aim of this study was to reveal the efficiency of the anti-inflammatory effect derived from onion nanoparticles to propose an advantage of eating onions without excessive food-processing. Specifically, we purified the nanoparticles from onions according to the exosome preparation method to evaluate their anti-inflammatory properties and cellular uptake in LPS-stimulated RAW264 cells.

\section{Results}

\subsection{Profiles of $17 \mathrm{Kp}$ and $200 \mathrm{Kp}$}

After centrifugation at $17,000 \times g$ and $200,000 \times g$, apparent pellets with a faint yellow color were observed, and we referred to them as $17 \mathrm{Kp}$ and $200 \mathrm{Kp}$, respectively.

(Figure 1A). These pellets were suspended in the phosphate buffered saline and passed through the $0.45 \mu \mathrm{m}$ membrane filter to evaluate their diameters of $17 \mathrm{Kp}$ and $200 \mathrm{Kp}$. The diameters of $17 \mathrm{Kp}$ and $200 \mathrm{Kp}$ could not be measured without membrane filtration. The average diameters of $17 \mathrm{Kp}$ and $200 \mathrm{Kp}$ were $288.1 \mathrm{~nm}$ and $185.3 \mathrm{~nm}$, respectively, and the size distribution data showed that more than $80 \%$ of $200 \mathrm{Kp}$ was less than $300 \mathrm{~nm}$.

(Figure 1B,C). To estimate the content of $17 \mathrm{Kp}$ and $200 \mathrm{Kp}$, proteins and small-sized RNA were extracted and detected by electrophoresis. SDS-PAGE and silver-staining data showed that $17 \mathrm{Kp}$ and $200 \mathrm{Kp}$ contained proteins; although the protein profile was similar between onion juice of $17 \mathrm{Kp}$ and $200 \mathrm{Kp}$, some bands were specifically detected at $200 \mathrm{Kp}$, highlighted as red arrows (Figure 1D). Figure 1E shows the electrophoresis image of the small RNA analysis. Several previous reports revealed that nanoparticles derived from edible plants included small RNA, such as miRNAs; we purified small RNA from the total RNA extract, and RNaseA treatment was performed to verify the RNA detection. Data showed that both $17 \mathrm{Kp}$ and $200 \mathrm{Kp}$ included small (20 80 bp)-sized RNA.

(Figure 1E). Then, we measured representative flavonoids in onion quercetin, $Q 4^{\prime} \mathrm{G}$, and $\mathrm{Q} 3,4^{\prime} \mathrm{G}$. Here, $48 \mathrm{~mL}$ juice was prepared from two onions for the preparation of $17 \mathrm{Kp}$ and $200 \mathrm{Kp}$, therefore, their juice contains $17 \mathrm{Kp}$ and $200 \mathrm{Kp}$. Quercetins were extracted by methanol then quercetins content in $48 \mathrm{~mL}$ juice as encapsulated in $17 \mathrm{Kp}$ and $200 \mathrm{Kp}$ were measured and data were shown as $\mu \mathrm{g} / \mathrm{mL}$ juice and \% of juice (Table 1 ). Most of the quercetins occurred as glucosides in juice, $17 \mathrm{Kp}$ and $200 \mathrm{Kp}$. Here, juice was a liquid 
before $17,000 \times g$ centrifugation, therefore, included $17 \mathrm{Kp}$ and $200 \mathrm{Kp}$. Total quercetin (quercetin + $4^{\prime} \mathrm{G}+\mathrm{Q} 3,4^{\prime} \mathrm{G}$ ) concentrations in juice, $17 \mathrm{Kp}$ and $200 \mathrm{Kp}$ were 171.5, 7.7 and $3.8 \mu \mathrm{g} / \mathrm{mL}$ juice; therefore, $4.5 \%$ and $2.2 \%$ of total quercetins in juice were estimated to be encapsulated in $17 \mathrm{Kp}$ and $200 \mathrm{Kp}$. Q3G and other flavonoids were not detected in any of the samples studied.

A

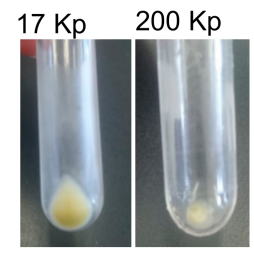

B

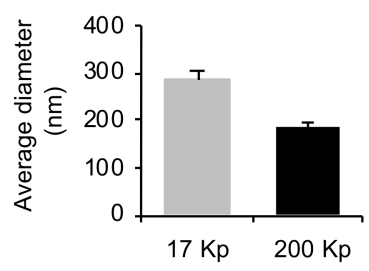

C

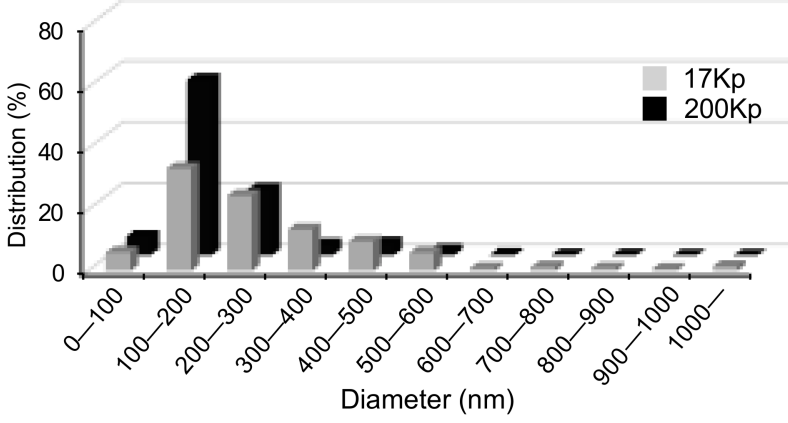

$\mathrm{D}$

$\mathrm{E}$
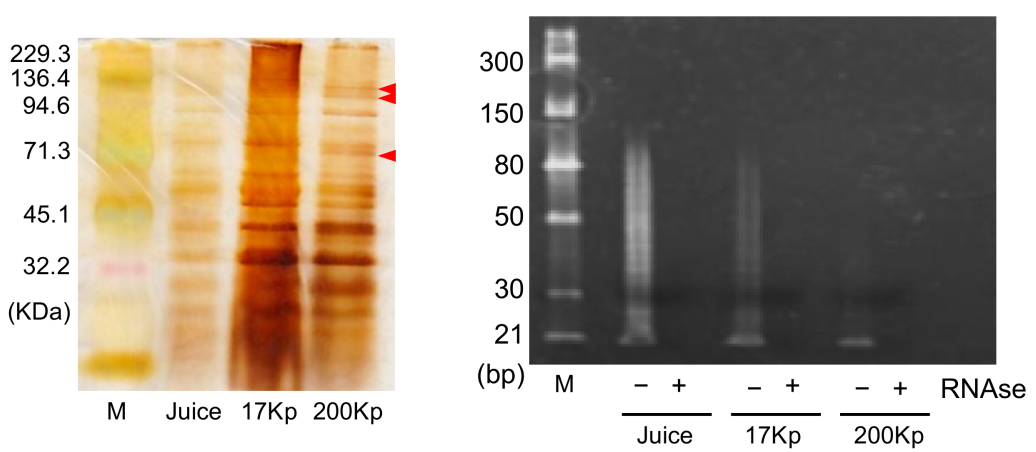

Figure 1. Profiles of nanoparticles identified from Allium cepa L. Nanoparticles were identified as $17,000 \times g$ and $200,000 \times g$ precipitates, referred to as $17 \mathrm{Kp}$ and $200 \mathrm{Kp}$, respectively. (A): Appearance of $17 \mathrm{Kp}$ and $200 \mathrm{Kp}$; (B,C): Diameters of $17 \mathrm{Kp}$ and $200 \mathrm{Kp}$ were measured by dynamic light scattering method. B shows the average diameter and $\mathrm{C}$ shows the distribution of the diameter. (D): Protein profiles analyzed by SDS-PAGE and silver staining. Red arrows show specific bands found in $200 \mathrm{Kp}$. (E): Small RNA profiles analyzed by PAGE. Small RNA purified from $17 \mathrm{Kp}$ and $200 \mathrm{Kp}$ were treated with or without RNAseA before loading to the electrophoresis.

Table 1. Content of quercetins in onion juice, $17 \mathrm{Kp}$ and $200 \mathrm{Kp}$.

\begin{tabular}{cccc}
\hline$\mu \mathrm{g} / \mathrm{mL}$ Juice & Juice & $\mathbf{1 7} \mathbf{~ K p}$ & $\mathbf{2 0 0 ~ K p}$ \\
\hline Quercetin & $4.92 \pm 2.00$ & $0.15 \pm 0.05$ & $0.12 \pm 0.03$ \\
$\mathrm{Q}^{\prime} \mathrm{G}$ & $68.6 \pm 16.0^{\mathrm{a}}$ & $4.68 \pm 1.85^{\mathrm{b}}$ & $1.61 \pm 0.44^{\mathrm{b}}$ \\
$\mathrm{Q} 34^{\prime} \mathrm{G}$ & $98.0 \pm 19.7^{\mathrm{a}}$ & $2.85 \pm 0.77^{\mathrm{b}}$ & $2.07 \pm 0.58^{\mathrm{b}}$ \\
\hline
\end{tabular}

Data are means \pm SE for 3 measurements. Data without any common alphabetic letter are significantly different each other at $p<0.05$. 


\subsection{Effect of $17 \mathrm{Kp}$ and $200 \mathrm{Kp}$ on LPS Response}

To evaluate the physiological function, the effect of $17 \mathrm{Kp}$ and $200 \mathrm{Kp}$ on NO production from LPS-treated RAW264 cells was measured. Cells were treated with $17 \mathrm{Kp}$ and $200 \mathrm{Kp}$ for $24 \mathrm{~h}$, and then treated with $100 \mathrm{ng} / \mathrm{mL}$ of LPS for $24 \mathrm{~h}$. Cell viability was also examined, but no cytotoxic effect of $17 \mathrm{Kp}$ and $200 \mathrm{Kp}$ was observed at any given concentrations (Figure 2A). LPS drastically increased NO production, whereas both $17 \mathrm{Kp}$ and $200 \mathrm{Kp}$ significantly inhibited it at 50-400 and $100-400 \mu \mathrm{g}$ protein $/ \mathrm{mL}$, respectively.

A
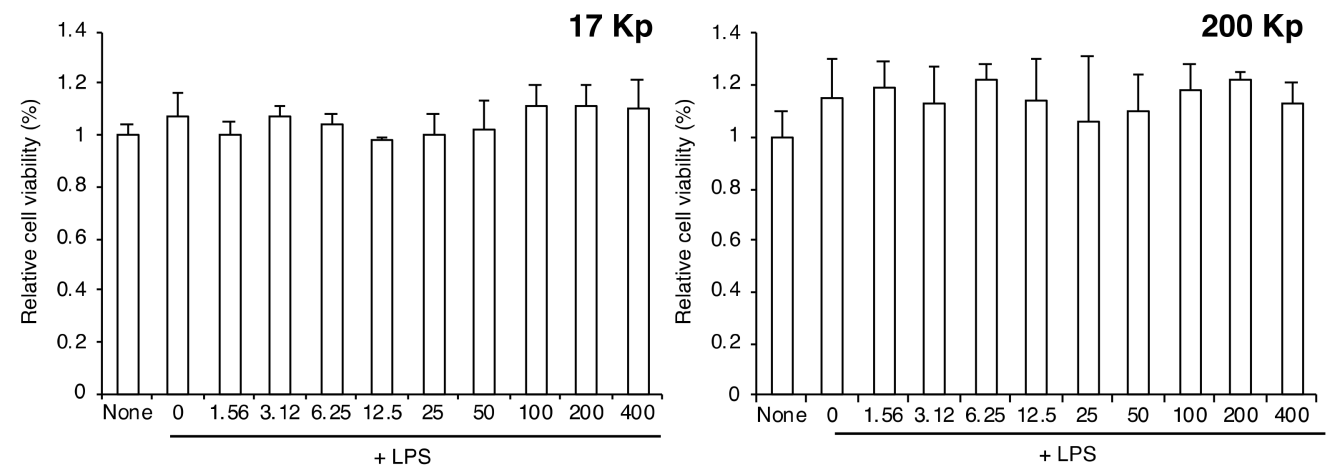

B
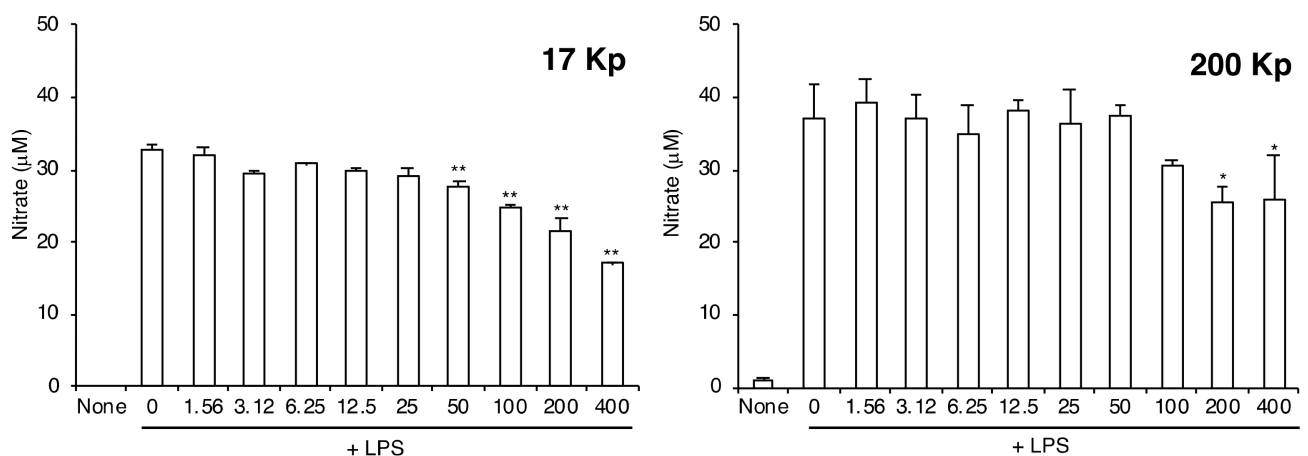

Figure 2. Effect of $17 \mathrm{Kp}$ and $200 \mathrm{Kp}$ on the nitric oxide production in lipopolysaccharide (LPS)treated RAW264 cells. Cell were treated with $17 \mathrm{Kp}$ or $200 \mathrm{Kp}$ for $24 \mathrm{~h}$ then treated with or without LPS (100 ng/mL) for $24 \mathrm{~h}$. (A): Cytotoxicity was evaluated by using Cell Counting Kit-8, and data are shown as relative cell viability (data in none were shown as 1 ). (B): Nitric oxide was detected as nitrate by Griess method. Data are means \pm SE for 3 experiments. Asterisk indicates significant difference from the $0+$ LPS group at $p<0.05,{ }^{* *} p<0.01$.

(Figure 2B). The precise number or weight of the nanoparticles cannot be measured; therefore, we expressed the amount of $17 \mathrm{Kp}$ and $200 \mathrm{Kp}$ as concentrations of proteins. The $17 \mathrm{Kp}$ and $200 \mathrm{Kp}$ had no effect on the NO production without LPS treatment (data not shown).

\subsection{Intracellular Incorporation of $17 \mathrm{Kp}$ and $200 \mathrm{Kp}$}

We then evaluated the incorporation of $17 \mathrm{Kp}$ and $200 \mathrm{Kp}$ into RAW264 cells. Here, we found that $17 \mathrm{Kp}$ and $200 \mathrm{Kp}$ were well stained with PKH26, which is a red fluorescent dye used for staining lipophilic membranes and extracellular vesicles [14]. To verify the occurrence of lipids, we extracted lipids by a chloroform: methanol (2:1) solution from the $17 \mathrm{Kp}$ and $200 \mathrm{Kp}$ samples and found that they included 313.7 and $150.2 \mathrm{mg}$ lipids/mg protein, respectively. PKH26-stained $17 \mathrm{Kp}$ and $200 \mathrm{Kp}$ were clearly observed in the intracellular regions of RAW264 cells after $2 \mathrm{~h}$ of treatment (Figure 3). 


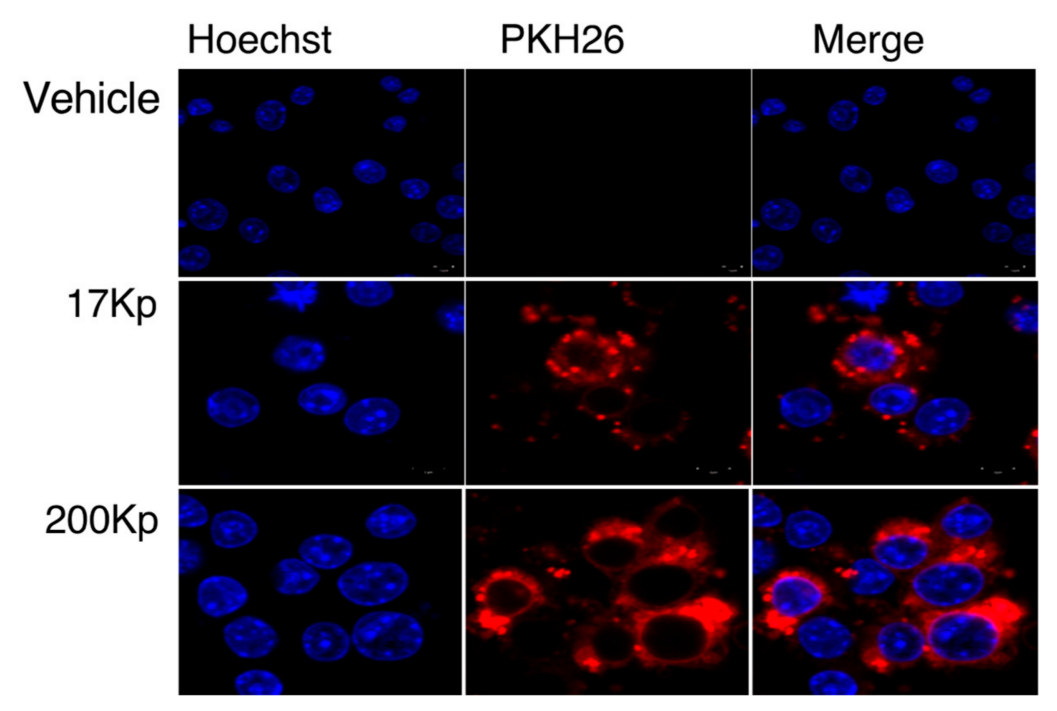

Figure 3. Intracellular incorporation of $17 \mathrm{Kp}$ and $200 \mathrm{Kp}$ into RAW264 cells. The $17 \mathrm{Kp}$ or $200 \mathrm{Kp}$ were stained with PKH26. Cells were treated with $400 \mu \mathrm{g}$ protein/mL $17 \mathrm{Kp}$ or $200 \mathrm{Kp}$ for $2 \mathrm{~h}$. Then, the nuclei were stained with Hoechst33342. Cells were observed by confocal laser microscope.

\subsection{Effect Endocytosis Inhibitors on PKH26 Stained $17 \mathrm{Kp}$ and $200 \mathrm{Kp}$ Uptake}

To clarify the intracellular uptake mechanism of $17 \mathrm{Kp}$ and $200 \mathrm{Kp}$, the cells were cotreated with M $\beta C D$ (inhibitor for caveolae-dependent endocytosis) or LY294002 (inhibitor for macropinocytosis) (Figures 4 and 5). The fluorescence intensity of PKH26 was quantified for the cellular uptake of $17 \mathrm{Kp}$ and $200 \mathrm{Kp}$. Interestingly, both M $\beta C D$ and LY294002 incompletely but significantly prevented the uptake of $17 \mathrm{Kp}$ and $200 \mathrm{Kp}$. Chlorpromazine, an inhibitor for clathrin-dependent endocytosis, failed to prevent the uptake of $17 \mathrm{Kp}$ and $200 \mathrm{Kp}$ (data not shown). Based on these results, we examined the effect of these inhibitors on the function of $17 \mathrm{Kp}$ and $200 \mathrm{Kp}$. Unexpectedly, M $\beta C D$ and LY294 did not affect the $17 \mathrm{Kp}$ - and $200 \mathrm{Kp}$-induced inhibition of NO production in LPS-treated cells (Figure 6).
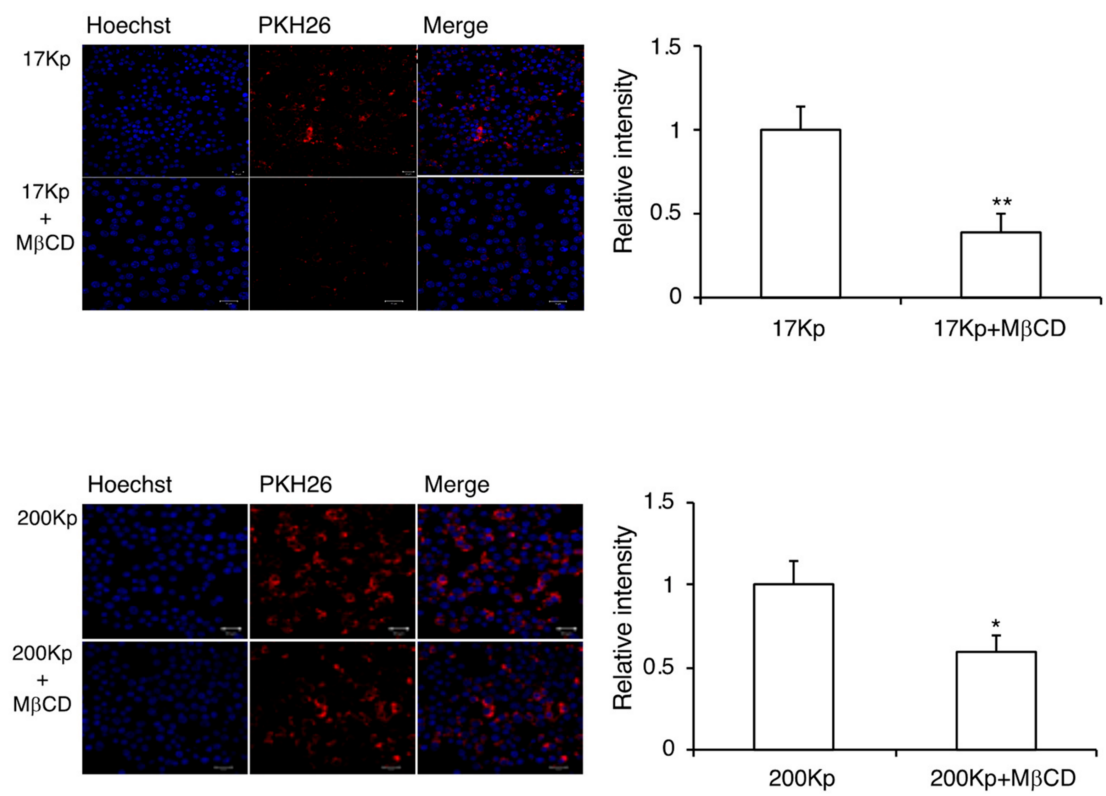

Figure 4. Effect of the clathrin-dependent endocytosis inhibitor on the intracellular incorporation of $17 \mathrm{Kp}$ and $200 \mathrm{Kp}$ into RAW264 cells. The $17 \mathrm{Kp}$ or $200 \mathrm{Kp}$ were stained with PKH26. Cells were treated with $10 \mathrm{mM}$ of M $\beta C D$ for $1 \mathrm{~h}$, then $400 \mu \mathrm{g}$ protein $/ \mathrm{mL} 17 \mathrm{Kp}$ or $200 \mathrm{Kp}$ for $2 \mathrm{~h}$. Nuclei were stained with Hoechst33342. Cells were observed by confocal laser microscope. Asterisk indicates significant difference from the $17 \mathrm{Kp}$ or $200 \mathrm{Kp}$ group at ${ }^{*} p<0.05,{ }^{* *} p<0.01$. 


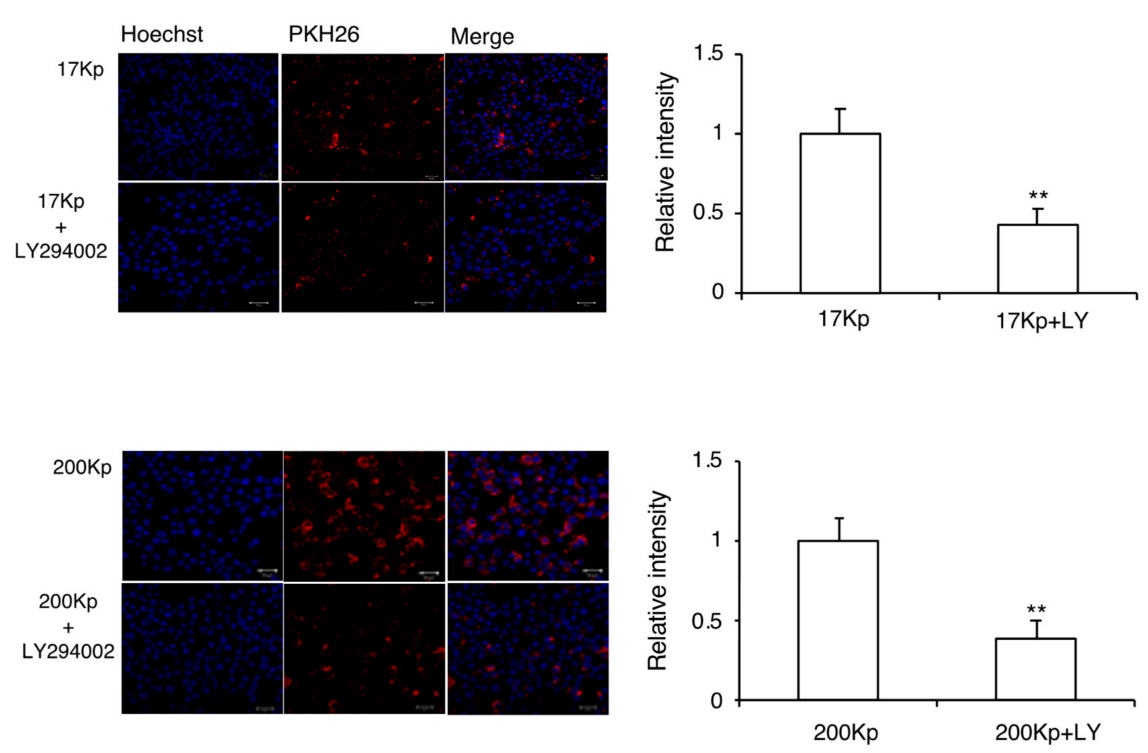

Figure 5. Effect of the macropinocytosis inhibitor on the intracellular incorporation of $17 \mathrm{Kp}$ and $200 \mathrm{Kp}$ into RAW264 cells. The $17 \mathrm{Kp}$ or $200 \mathrm{Kp}$ were stained with PKH26. Cells were treated with $50 \mu \mathrm{M}$ of LY294002 for $1 \mathrm{~h}$, then $400 \mu \mathrm{g}$ protein/mL $17 \mathrm{Kp}$ or $200 \mathrm{Kp}$ for $2 \mathrm{~h}$. Nuclei were stained with Hoechst33342. Cells were observed by confocal laser microscope. Asterisk indicates significant difference from the $17 \mathrm{Kp}$ or $200 \mathrm{Kp}$ group at ${ }^{* *} p<0.01$.

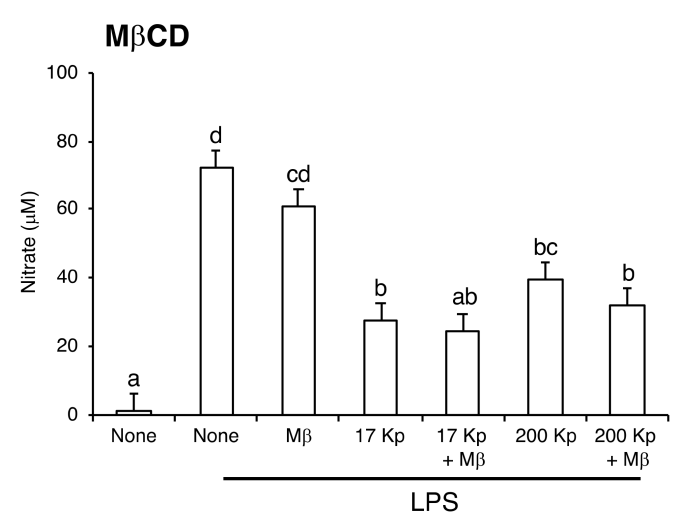

\section{LY294002}

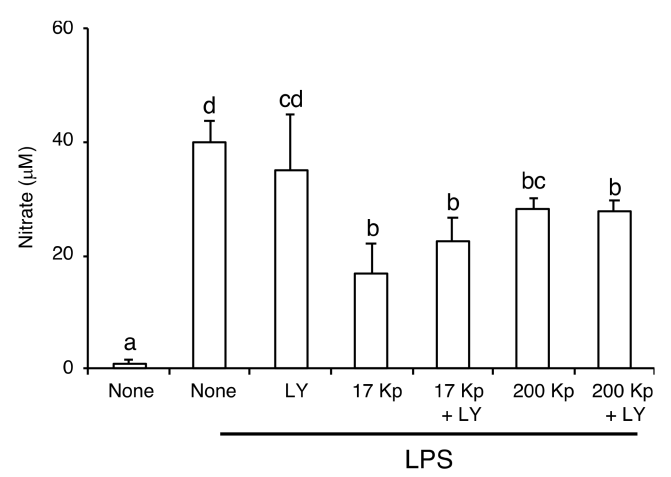

Figure 6. Effect of endocytosis inhibitors on the nitric oxide production in lipopolysaccharide (LPS)treated RAW264 cells. Cell were treated with $400 \mu \mathrm{g}$ protein/mL of $17 \mathrm{Kp}$ or $200 \mathrm{Kp}$ for $24 \mathrm{~h}$, then treated with or without inhibitors for $1 \mathrm{~h}$. Finally, cells were treated with LPS (100 ng/mL) for $24 \mathrm{~h}$. Nitric oxide was detected as nitrate by Griess method. Data are shown as mean \pm SE for 3 experiments. Data without any common alphabetic letter are significantly different each other at $p<0.05$. 


\section{Discussion}

In the present study, we evaluated the anti-inflammatory properties of onion-derived nanoparticles on RAW264 cells. First, we succeeded in preparing $17 \mathrm{Kp}$ and $200 \mathrm{Kp}$ according to the method used for the purification of exosomes $[18,19]$. In addition, dynamic light scattering analysis and electrophoresis data showed that both $17 \mathrm{Kp}$ and $200 \mathrm{Kp}$ were similar to the exosome, in that they were nano-sized and included proteins and small sized RNA (Figure 1). Here, we did not measure the zeta potential that enables the prediction of aggregation. We performed $0.45 \mu \mathrm{m}$ filtration to eliminate the large size of particles that strongly influence the dynamic light scattering analysis even if the nanoparticle content is extremely low. Actually, without filtering we could not acquire the data indicating the occurrence of a large particle. As for HPLC and cell culture experiments, we quickly applied for the experiment just after the thawing; on the other hand, it took a few hours after thawing for dynamic light scattering analysis to indicate that partial aggregation might occur in a few hours' time. Presently, we did not identify the specific proteins in $200 \mathrm{Kp}$, but these proteins are likely molecular markers for the nanovesicles, such as CD9, CD63, and CD81, in the exosome [20]. Several previous studies, in which nanoparticles were purified from various edible plants, showed that miRNA was present in the nanoparticles [21,22]. This information implies that an edible plant derived might be vectors of small RNA to predator cells result in the regulation of the gene expression. Artificial nanoparticles and animal-derived exosomes are being attracted as putative materials for drug delivery [23] and edible plant-derived nanoparticles containing plant-derived miRNAs are also emerging candidates for the therapeutics of various diseases [24,25]. Of note, plant RNAs are capable of modulating immune function such as the regulation of response to TLR-4 stimulation in dendritic cells [26]. Our data also showed that $17 \mathrm{Kp}$ and $200 \mathrm{Kp}$ included small-sized (20 80 bp) RNA; therefore, small-sized RNA, such as miRNAs, might modulate the gene expression in cells treated with $17 \mathrm{Kp}$ and $200 \mathrm{Kp}$. Several miRNAs have been identified in the onion [27].

It has been reported that onion juice and peel extract-attenuated LPS response in colon carcinoma and LPS-induced osteoclastogenesis in RAW264.7 cells [16,17]. Our preliminary data also showed that onion juice suppressed LPS-induced NO production in RAW264 cells, verifying the inhibition of the LPS response. The onion contains several polyphenols, and quercetin and its glucoside can exert health benefits. Quercetin was partly responsible for the inhibition of the LPS response in RANKL/LPS-induced osteoclastogenesis in RAW264.7 cells [28]. The onion juice used in this study contained 4.9, 68.6, and $98.0 \mu \mathrm{g} / \mathrm{mL}$ of quercetin, Q-4' $\mathrm{G}$, and Q-3, $4^{\prime} \mathrm{G}$, respectively. This is similar to previous reports [29,30]. The total quercetin (quercetin $+Q-4^{\prime} \mathrm{G}+\mathrm{Q}-3,4^{\prime} \mathrm{G}$ ) concentration in juice, including $17 \mathrm{Kp}$ and $200 \mathrm{Kp}$, was $171.5 \mu \mathrm{g} / \mathrm{mL}$. Table 1 shows that $17 \mathrm{Kp}$ and $200 \mathrm{Kp}$ also contained 7.7 and $3.8 \mu \mathrm{g} / \mathrm{mL}$, representing 4.5 and $2.2 \%$ of quercetins, respectively, of these flavonoids, suggesting that they are polyphenol-inclusive vesicles. Both particles were faint yellow in appearance. Quercetins are yellow pigmented and form in vacuoles in the soluble sugarbinding form in the plant cells; therefore, $17 \mathrm{Kp}$ and $200 \mathrm{Kp}$ might contain vacuole-derived intracellular or extracellular particles.

Figure 2 shows that $17 \mathrm{Kp}$ and $200 \mathrm{Kp}$ inhibited the production of NO in a dosedependent manner. The sample concentrations are shown as protein levels, because we could not precisely quantify the number and weight of the samples. For instance, $400 \mu \mathrm{g} / \mathrm{mL}$ of protein corresponded to 581 and $260 \mathrm{ng} / \mathrm{mL}(1.1 \mu \mathrm{M}$ and $0.48 \mu \mathrm{M}$, respectively) of the total quercetins. Significant effects were observed from both $17 \mathrm{Kp}$ and $200 \mathrm{Kp}$ at a concentration of $200 \mu \mathrm{g} / \mathrm{mL}$. Moreover, $17 \mathrm{Kp}$ showed a significant effect at $50 \mu \mathrm{g} / \mathrm{mL}$ $(137.5 \mathrm{nM})$. It is possible that these concentrations are too low to exert an inhibitory effect on LPS response. In addition, none of the quercetins were detected in cells treated with $17 \mathrm{Kp}$ and $200 \mathrm{Kp}$. It was considered that at $17 \mathrm{Kp}$ and $200 \mathrm{Kp}$, flavonoid capsules occur-at least in flesh juice. However, quercetins encapsulated in $17 \mathrm{Kp}$ and $200 \mathrm{Kp}$ were not involved in the anti-inflammatory properties or further applications, quercetin nanoparticles are gaining attention as potent cancer therapeutic materials [31]. 
The exosome is an extracellular nanoparticle ubiquitously released from cells in animal tissues and organs. Exosomes include proteins, lipids, mRNA, and miRNA, and are absorbed by target cells. This results in a change in mRNA expression and the cellular phenotype. In this study, we hypothesized that $17 \mathrm{Kp}$ and $200 \mathrm{Kp}$ exert their effects by their cellular uptake via an endocytosis approach [32]. Confocal laser microscope images indicated that PKH26-stained $17 \mathrm{Kp}$ and $200 \mathrm{Kp}$ were absorbed by RAW264 cells, and this absorption was prevented by M $\beta C D$ or LY294002 treatment. These data indicated that $17 \mathrm{Kp}$ and $200 \mathrm{Kp}$ were absorbed via a caveolae-mediated endocytosis and macropinocytosis. One possibility was that cellular uptake was indispensable for the effect on RAW264 cells; however, endocytosis inhibitors failed to prevent the inhibitory effect of $17 \mathrm{Kp}$ and $200 \mathrm{Kp}$ on NO production. Another possibility is that both endocytotic pathways synergistically contribute to the effect of $17 \mathrm{Kp}$ and $200 \mathrm{Kp}$. Confocal microscope observation clearly showed the intracellular incorporation of $17 \mathrm{Kp}$ and $200 \mathrm{Kp}$, although quercetin and its glucosides were not detected from cell lysates. These data imply a low efficiency of cellular incorporation of $17 \mathrm{Kp}$ and $200 \mathrm{Kp}$. At this point, both $17 \mathrm{Kp}$ and $200 \mathrm{Kp}$ must not be homogenous in terms of their physical properties and chemical components; therefore, specific particles may be efficiently incorporated and be responsible for the effect on RAW264 cells.

Previous reports, in which nanoparticles were purified from edible plants, showed that nanoparticles were structured like lipid membranes and contained phospholipids; however, their profiles were distinct from each other [24]. Although we also confirmed that $17 \mathrm{Kp}$ and $200 \mathrm{Kp}$ contained 313.7 and $150.2 \mathrm{mg}$ lipids/mg protein, respectively, the extracted lipid treatment of RAW264 failed to prevent the LPS response (data not shown). This study could not completely repudiate the relationship between lipid involvement and the function of $17 \mathrm{Kp}$ and $200 \mathrm{Kp}$. Further studies are needed to clarify the molecular mechanism of $17 \mathrm{Kp}$ and $200 \mathrm{Kp}$ on RAW264 cells and to evaluate the additional beneficial effects of $17 \mathrm{Kp}$ and $200 \mathrm{Kp}$.

At first, we have shown that the anti-inflammatory effect of nanoparticle from Allium cepa L. It is estimated that the structure and content of nanoparticle might be collapsed or denatured during food processing such as heating, drying, high pressure and extraction. Finally, we propose the advantage of eating Allium cepa L. without denaturing the nanoparticles to accomplish its potent anti-inflammatory activity.

\section{Materials and Methods}

\subsection{Preparation of Nanovesicles}

Allium cepa L. was purchased from a commercial supermarket in Miyazaki city and mashed with a food processor (MK-K48-W, National, Osaka, Japan); then, juice was obtained using a squeezer. Juice was recovered into $50 \mathrm{~mL}$ polycarbonate tubes and centrifuged at $1000 \times g$ for $5 \mathrm{~min}$ at room temperature to remove the residue. Supernatant was further centrifuged at $17,000 \times g$ for $15 \mathrm{~min}$, and its precipitates are referred to as $17 \mathrm{Kp}$ throughout this manuscript. The supernatant was further ultracentrifuged at $200,000 \times g$ for $1 \mathrm{~h}$, and those precipitates are referred to as $200 \mathrm{Kp}$ throughout this manuscript. Samples were reserved at $-80{ }^{\circ} \mathrm{C}$ before analysis. Diameters of the nanovesicles were measured by dynamic light scattering method using a SZ-100 nanoPartica series instrument (Horiba, Ltd., Kyoto, Japan).

\subsection{Small RNA Extraction and Purification}

Extraction of small RNA was performed using the miRNeasy Mini kit (Qiagen, Hilden, Germany) according to the manufacture's protocol. At the end of the procedure, $40 \mu \mathrm{L}$ of RNAase-free water was added to the spin column and centrifuged at $8000 \times g$ for $1 \mathrm{~min}$. The eluted solution was diluted 200-fold with RNAase-free water and analyzed by the following electrophoresis protocol. To verify the detection of RNA, samples were treated with $10 \mu \mathrm{g} / \mathrm{mL}$ of RNAseA (Sigma, St. Louis, MO, USA) at $37^{\circ} \mathrm{C}$ for $30 \mathrm{~min}$. 
Samples were separated by electrophoresis on a $15 \%$ SuperSep ${ }^{\mathrm{TM}}$ Ace polyacrylamide gel (Fujifilm Wako Pure Chemical Co., Osaka, Japan) and stained with ethidium bromide.

\subsection{Protein Analysis}

The preparation of cellular protein samples was performed according to our previous method [33]. The $17 \mathrm{Kp}$ and $200 \mathrm{Kp}$ samples were treated with lysate buffer $(50 \mathrm{mM}$ Tris$\mathrm{HCl}, 150 \mathrm{mM} \mathrm{NaCl}$, 2\% Triton-X 100, $1 \mathrm{mM}$ EDTA, $50 \mathrm{mM} \mathrm{NaF}, 30 \mathrm{mM} \mathrm{Na}_{4} \mathrm{P}_{2} \mathrm{O}_{7}$ ) including the $1 / 50$ vol. protease inhibitor cocktail (Nacalai, Kyoto, Japan). Protein concentrations were measured using the BCA protein assay reagent (Pierce, Rockford, IL, USA). Lysates containing $10 \mu \mathrm{g}$ of protein were separated by electrophoresis on a $10 \%$ SDS-polyacrylamide gel. Proteins were stained with 2D-Silver Stain Reagent II according to the appended protocol (Cosmo Bio, Tokyo, Japan).

\subsection{High-Performance Liquid Chromatography (HPLC) Analysis for the Detection of Quercetins}

Quercetins were quantified by using HPLC according to a previous report with some modifications [34]. To extract the flavonoids, $200 \mu \mathrm{L}$ of $50 \%$ methanol was added to $17 \mathrm{Kp}$ and $200 \mathrm{Kp}$ and sonicated. The solution was passed through a $0.45 \mu \mathrm{m} \mathrm{sy-}$ ringe filter (Merck, Darmstadt, Germany) before analysis. Quercetin and its glucosides, quercetin-4'-glucoside $\left(\mathrm{Q} 4^{\prime} \mathrm{G}\right)$ and quercetin-3, $4^{\prime}$-glucoside $\left(\mathrm{Q} 3,4^{\prime} \mathrm{G}\right)$, were measured by HPLC equipped with a PDA detector system at $360 \mathrm{~nm}$ (Shimadzu, Kyoto, Japan) using the ODS-2 column (GL Science, Tokyo, Japan) at $30^{\circ} \mathrm{C}$. The mobile phase consisted of methanol (A) and 0.5\% formic acid (B), and the employing gradient (0-5 min, A/B 5\% 5-15 $\min$ A/B 20\%, 15-20 min A/B 30\%, 20-30 min A/B 50\%, 30-35 min A/B 100\%) flowed at $1.0 \mathrm{~mL} / \mathrm{min}$. Accurately weighed quercetin (Cayman Chemical, MI, USA), Q4' G, and Q3,4'G (Tokiwa Phytochmical, Chiba, Japan) were dissolved in methanol to prepare the 1 $\mathrm{mg} / \mathrm{mL}$ stock solution and kept at $-30^{\circ} \mathrm{C}$ before analysis. Quercetins in the samples were identified by comparison with the retention times of these standards.

\subsection{Measurement of Nitric Oxide (NO) by RAW264 Cells}

RAW264 cells were purchased from Riken Cell Bank (RCB0535, Tsukuba, Japan). Cells were cultured in Dulbecco's modified Eagle medium (DMEM) supplemented with $10 \%$ fetal bovine serum (Sigma, MO, USA) and 1/100 vol. penicillin-streptomycin-amphotericin B cocktail (Fujifilm Wako). Cells (4th passage) were seeded at $1.8 \times 10^{4}$ cells $/ \mathrm{cm}^{2}$ in a $90 \mathrm{~mm}$ dish, and then maintained every second day to make the cells at the growth state. Experiments were done using cells within 24 passages after thawing. Cells were seeded at $5.0 \times 10^{4}$ cells $/ \mathrm{cm}^{2}$ and preculture for $24 \mathrm{~h}$ before analysis to reach to subconfluent (approximately 70\%). Then, the cells were treated with given concentrations of the samples in phenol red free DMEM for $24 \mathrm{~h}$; then, LPS (Sigma L6511) was added at $100 \mathrm{ng} / \mathrm{mL}$. After $24 \mathrm{~h}$ culture, cultured supernatant was recovered to measure the production of NO from RAW264 cells. NO production was measured as nitrate using the Griess method as the previous report [33]. Briefly, the supernatant was mixed with Griess reagent, $2.5 \%$ phosphoric acid, $1 \%$ sulfanilamide, and $0.1 \% \mathrm{~N}$-(1-Naphthyl) ethylene-diamine dihydrochloride, and absorbance was measured at $540 \mathrm{~nm}$. Cytotoxicity of the samples were measured using Cell Counting Kit-8 (Dojindo, Kumamoto, Japan).

\subsection{Staining and Observation of Nanovesicles}

Nanoparticles were stained with PKH26, as referred to in a previous report [35]. The $17 \mathrm{Kp}$ and $200 \mathrm{Kp}$ samples were suspended in $1.2 \mathrm{~mL}$ phosphate buffered saline and mixed with $600 \mu \mathrm{L}$ of PKH26 staining solution. This mixture was incubated at $37^{\circ} \mathrm{C}$ for $30 \mathrm{~min}$. Staining reaction was stopped by the addition of $1.8 \mathrm{~mL}$ of $1 \%$ bovine serum albumin. Then, the suspension was ultracentrifuged at $200,000 \times g$ for $1 \mathrm{~h}$ to recover the stained nanoparticles. To evaluate the cellular incorporation of $17 \mathrm{Kp}$ and $200 \mathrm{Kp}$, RAW264 cells were inoculated into $35 \mathrm{~mm}$ glass bottom dish (Iwaki 3911-035, Shizuoka, Japan). RAW264 cells were treated with PKH26-stained $17 \mathrm{Kp}$ and $200 \mathrm{Kp}$ for $2 \mathrm{~h}$, then nuclei were stained 
with $10 \mu \mathrm{g} / \mathrm{mL}$ Hoechst33342. Cells were mounted with 50\% glycerol and observed by confocal laser microscope LSM700 (Carl Zeiss, Oberkochen, Germany). The intensity of PKH26 red fluorescent was quantified by Leica Application Suite X software to evaluate the intensity of cellular incorporation. Ten micromolar of $\mathrm{M} \beta \mathrm{CD}$ (inhibitor for caveolaedependent endocytosis) or $50 \mu \mathrm{M}$ of LY294002 (inhibitor for macropinocytosis) were added $1 \mathrm{~h}$ before the $17 \mathrm{Kp}$ and $200 \mathrm{Kp}$ treatments.

\subsection{Statistical Analysis}

Statistical differences among experimental groups were evaluated by Student's $t$-test or Duncan's multiple range test (statistical analysis for Mac Ver.3.0, Esumi, Tokyo, Japan). The statistical significance was defined as $p<0.05$.

Author Contributions: Conceptualization, M.Y. and Y.Y.; methodology, R.F., H.K., M.I., H.S., I.K. and T.O.; validation, K.N. and K.O.; formal analysis, Y.Y., R.F., M.Y.; investigation, R.F., H.K.; data curation, R.F., M.Y.; writing—original draft preparation, M.Y.; writing—review and editing, Y.Y., H.S., M.I., I.K. and T.O.; visualization, M.Y.; supervision, M.Y.; resource, M.Y.; project administration, M.Y.; funding acquisition, M.Y. All authors have read and agreed to the published version of the manuscript.

Funding: This research was funded by KAKENHI (15K14736) and Japan Health Foundation (2018).

Institutional Review Board Statement: Not applicable.

Informed Consent Statement: Not applicable.

Data Availability Statement: Data contained within this article is available from the authors.

Acknowledgments: We would like to thank Madhyatsta Harishkumar for the proof reading of this manuscript.

Conflicts of Interest: The authors declare no conflict of interest.

Sample Availability: Samples are available from the authors.

\section{References}

1. Slavin, J.L.; Lloyd, B. Health benefits of fruits and vegetables. Adv. Nutr. 2012, 3, 506-516.

2. Locke, A.; Schneiderhan, J.; Zick, S.M. Diets for Health: Goals and Guidelines. Am. Fam. Physician 2018, $97,721$.

3. Wesselink, E.; Koekkoek, W.A.C.; Grefte, S.; Witkamp, R.F.; van Zanten, A.R.H. Feeding mitochondria: Potential role of nutritional components to improve critical illness convalescence. Clin. Nutr. 2019, 38, 982-995. [CrossRef]

4. Gedi, M.A.; Briars, R.; Yuseli, F.; Zainol, N.; Darwish, R.; Salter, A.M.; Gray, D.A. Component analysis of nutritionally rich chloroplasts: Recovery from conventional and unconventional green plant species. J. Food Sci. Technol. 2017, 54, $2746-2757$. [CrossRef]

5. Liu, D.; Lopez-Sanchez, P.; Gidley, M.J. Cellular barriers in apple tissue regulate polyphenol release under different food processing and in vitro digestion conditions. Food Funct. 2019, 10, 3008-3017. [CrossRef]

6. Mu, J.; Zhuang, X.; Wang, Q.; Jiang, H.; Deng, Z.B.; Wang, B.; Zhang, L.; Kakar, S.; Jun, Y.; Miller, D.; et al. Interspecies communication between plant and mouse gut host cells through edible plant derived exosome-like nanoparticles. Mol. Nutr. Food Res. 2014, 58, 1561-1573. [CrossRef] [PubMed]

7. Baldini, N.; Torreggiani, E.; Roncuzzi, L.; Perut, F.; Zini, N.; Avnet, S. Exosome-like nanovesicles isolated from citrus limon L. exert antioxidative effect. Curr. Pharm. Biotechnol. 2018, 19, 877-885. [CrossRef] [PubMed]

8. Teng, Y.; Ren, Y.; Sayed, M.; Hu, X.; Lei, C.; Kumar, A.; Hutchins, E.; Mu, J.; Deng, Z.; Luo, C.; et al. Plant-derived exosomal microRNAs shape the gut microbiota. Cell Host Microbe 2018, 24, 637-652. [CrossRef] [PubMed]

9. Xiao, J.; Feng, S.; Wang, X.; Long, K.; Luo, Y.; Wang, Y.; Ma, J.; Tang, Q.; Jin, L.; Li, X.; et al. Identification of exosome-like nanoparticle-derived microRNAs from 11 edible fruits and vegetables. PeerJ 2018, 6, e5186. [CrossRef]

10. Cui, J.; Zhou, B.; Ross, S.A.; Zempleni, J. Nutrition, microRNAs, and human health. Adv Nutr 2018, 8, 105-112. [CrossRef]

11. Woith, E.; Melzig, M.F. Extracellular vesicles from fresh and dried plants-Simultaneous purification and visualization using gel electrophoresis. Int. J. Mol. Sci. 2019, 20, 357. [CrossRef]

12. Marrelli, M.; Amodeo, V.; Statti, G.; Conforti, F. Biological properties and bioactive components of Allium cepa L.: Focus on potential benefits in the treatment of obesity and related comorbidities. Molecules 2018, 24, 119. [CrossRef] [PubMed]

13. Yoshinari, O.; Shiojima, Y.; Igarashi, K. Anti-obesity effects of onion extract in Zucker diabetic fatty rats. Nutrients 2012, 4, 1518-1526. [CrossRef]

14. Kim, O.Y.; Lee, S.M.; Do, H.; Moon, J.; Lee, K.H.; Cha, Y.J.; Shin, M.J. Influence of quercetin-rich onion peel extracts on adipokine expression in the visceral adipose tissue of rats. Phytother. Res. 2012, 26, 432-437. [CrossRef] 
15. Shaik, Y.B.; Castellani, M.L.; Perrella, A.; Conti, F.; Salini, V.; Tete, S.; Madhappan, B.; Vecchiet, J.; De Lutiis, M.A.; Caraffa, A.; et al. Role of quercetin (a natural herbal compound) in allergy and inflammation. J. Biol. Regul. Homeostat. Agents 2016, $20,47-52$.

16. Kim, J.; Kim, J.S.; Park, E. Cytotoxic and anti-inflammatory effects of onion peel extract on lipopolysaccharide stimulated human colon carcinoma cells. Food Chem. Toxicol. 2013, 62, 199-204. [CrossRef]

17. Tang, C.H.; Huang, T.H.; Chang, C.S.; Fu, W.M.; Yang, R.S. Water solution of onion crude powder inhibits RANKL-induced osteoclastogenesis through ERK, p38 and NF-kappaB pathways. Osteoporosis Int. 2009, 20, 93-103. [CrossRef] [PubMed]

18. Oshikawa, S.; Sonoda, H.; Ikeda, M. Aquaporins in urinary extracellular vesicles (Exosomes). Int. J. Mol. Sci. 2016, 17, 957. [CrossRef]

19. Sonoda, H.; Lee, B.R.; Park, K.-H.; Nihalani, D.; Yonn, J.-H.; Ikeda, M.; Kwon, S.-H. miRNA profiling of urinary exosomes to assess the progression of acute kidney injury. Sci. Rep. 2019, 9, 4692. [CrossRef] [PubMed]

20. Kowal, J.; Arras, G.; Colombo, M.; Jouve, M.; Morath, J.P.; Primdal-Bengtson, B.; Dingli, F.; Loew, D.; Tkach, M.; Théry, C. Proteomic comparison defines novel markers to characterize heterogeneous populations of extracellular vesicle subtypes. Proc. Natl. Acad. Sci. USA 2016, 113, E968-E977. [CrossRef]

21. Zhang, J.; Li., S.; Li, L.; Li, M.; Guo, C.; Yao, J.; Mi, S. Exosome and exosomal microRNA: Trafficking, sorting, and function. Genom. Proteom. Bioinform. 2015, 13, 17-24. [CrossRef]

22. Yu, X.; Odenthal, M.; Fries, J.W. Exosomes as miRNA Carriers: Formation-Function-Future. Int. J. Mol. Sci. 2016, 17, 2028. [CrossRef] [PubMed]

23. Kishita, K.; Ibaraki, K.; Itakura, S.; Yamasaki, Y.; Nishikata, N.; Yamamoto, K.; Shimizu, M.; Nishiyama, K.; Yamasaki, M. Preparation of conjugated linoleic acid microemulsions and their biodistribution. J. Oleo Sci. 2016, 65, 949-954. [CrossRef] [PubMed]

24. Zhang, M.; Viennois, E.; Xu, C.; Merilin, D. Plant derived nanoparticles as a new therapeutic approach against diseases. Tissue Barriers 2016, 4, e1134415. [CrossRef] [PubMed]

25. Iravani, S.; Varma, R.S. Plant-derived edible nanoparticles and miRNAs: Emerging frontier for therapeutics and targeted drug-delivery. ACS Sustain. Chem. Eng. 2019, 9, 8055-8069. [CrossRef]

26. Cavalieri, D.; Rizzetto, L.; Tocci, N.; Rivero, D.; Asquini, E.; Si-Ammour, A.; Bonechi, E.; Ballerini, C.; Viola, R. Plant microRNAs as novel immunomodulatory agents. Sci. Rep. 2016, 6, 25761. [CrossRef]

27. Zhang, Z.; Yu, J.; Li, D.; Zhang, Z.; Liu, F.; Zhou, X.; Wang, T.; Ling, Y.; Su, Z. PMRD: Plant microRNA database. Nucleic Acids Res. 2010, 38, D806-D813. [CrossRef] [PubMed]

28. Oliveira, T.; Figueiredo, C.A.; Brito, C.; Stavroullakis, A.; Ferreira, A.C.; Nogueira-Filho, G.; Prakki, A. Allium cepa L. and Quercetin inhibit RANKL/Porphyromonas gingivalis LPS-induced osteoclastogenesis by downregulating NF-kB signaling pathway. Evid. Based Complement. Altern. Med. 2015, 2015, 704781. [CrossRef]

29. Patil, B.S.; Pike, L.M.; Yoo, K.S. Variation in the quercetin content in different colored onions (Allium cepa L.). J. Am. Soc. Hortic. Sci. 1995, 120, 909-913. [CrossRef]

30. Caridi, D.; Trenerry, V.C.; Rochfort, S.; Duong, S.; Laugher, D.; Jones, R. Profiling and quantifying quercetin glucosides in onion (Allium cepa L.) varieties using capillary zone electrophoresis and high performance liquid chromatography. Food Chem. 2007, 105, 691-699. [CrossRef]

31. Ren, K.W.; Li, Y.H.; Wu, G.; Ren, J.Z.; Lu, H.B.; Li, Z.M.; Han, X.W. Quercetin nanoparticles display antitumor activity via proliferation inhibition and apoptosis induction in liver cancer cells. Int. J. Oncol. 2017, 50, 1299-1311. [CrossRef]

32. Tian, T.; Zhu, Y.L.; Zhou, Y.Y.; Liang, G.F.; Wang, Y.Y.; Hu, F.H.; Xiao, Z.D. Exosome uptake through clathrin-mediated endocytosis and macropinocytosis and mediating miR-21 delivery. J. Biol. Chem. 2014, 289, 22258-22267. [CrossRef] [PubMed]

33. Imamura, K.; Asai, M.; Sugamoto, K.; Matsumoto, T.; Yamasaki, Y.; Kamei, I.; Hattori, T.; Kishimoto, M.; Niisaka, S.; Kubo, M.; et al. Suppressing effect of cordycepin on the lipopolysaccharide-induced nitric oxide production in RAW 264.7 cells. Biosci. Biotechnol. Biochem. 2015, 79, 1021-1025. [CrossRef]

34. Watanabe, J.; Muro, T.; Yanagida, D.; Yamagishi, T.; Takano-Ishikawa, Y. Varietal differences in quercetin contents and antioxidant capacities of onions. Nippon Shokuhin Kagaku Kogaku Kaishi 2013, 10, 563-566. [CrossRef]

35. Pužar Dominkuš, P.; Stenovec, M.; Sitar, S.; Lasič, E.; Zorec, R.; Plemenitaš, A.; Žagar, E.; Kreft, M.; Lenassi, M. PKH26 labeling of extracellular vesicles: Characterization and cellular internalization of contaminating PKH26 nanoparticles. Biochim. Biophys. Acta-Biomembr. 2018, 1860, 1350-1361. [CrossRef] [PubMed] 